\title{
PHYSIOLOGICAL QUALITY OF SOYBEAN SEEDS UNDER MECHANICAL INJURIES CAUSED BY COMBINES ${ }^{1}$
}

\author{
FÁBIO PALCZEWSKI PACHECO ${ }^{2 *}$, LÚCIA HELENA PEREIRA NÓBREGA ${ }^{2}$, GISLAINE PICOLLO DE LIMA ${ }^{2}$, \\ MÁRCIA SANTORUM ${ }^{2}$, WALTER BOLLER ${ }^{3}$, LORIVAN FORMIGHIERI $^{3}$
}

\begin{abstract}
The mechanical harvesting causes injuries on seeds and may affect their quality. Different threshing mechanisms and their adjustments may also affect the intensity of impacts that machines cause on seeds. So, this study aimed at diagnosing and evaluating the effect of two combines: the first one with a threshing system of axial flow and the other one with a threshing system of tangential flow, under adjustments of concave opening $(10 \mathrm{~mm}, 30 \mathrm{~mm}$ and $10 \mathrm{~mm}$ for a combine with axial flow and $3.0 \mathrm{~mm}, 15 \mathrm{~mm}$ and $3.0 \mathrm{~mm}$ for a combine with tangential flow) and three cylinder rotations on the quality of soybean seeds harvested at two moisture contents. Soybean seeds of cultivar 'ND 4910' were harvested at 16.6\% moisture (mid-morning) and $13.7 \%$ moisture in the afternoon. The seeds quality was evaluated by germination tests, germination speed index (GSI), germination rate, moisture content, percentage of purity and vigor by tetrazolium test. Despite the combine, the results showed that the mechanical injury has most reduced seeds quality, at $16.6 \%$ moisture content, concave opening of $30 \mathrm{~mm}$ (axial) and $10 \mathrm{~mm}$ (tangential) and cylinder rotation of $1100 \mathrm{rpm}$ (axial) and 1000 (tangential), both with the highest rotations used. The combine with tangential flow had the highest degree of seeds purity. When seeds moisture content at harvest was close to $13.7 \%$, there was the highest seed injury, while, at $16.6 \%$, there was the highest number of crushed soybeans, regardless the combine adjustment.
\end{abstract}

Keywords: Glycine max. Combines adjustment. Cylinder rotation.

\section{QUALIDADE FISIOLÓGICA DE SEMENTES DE SOJA SUBMETIDAS A DANOS MECÂNICOS OCASIONADOS POR COLHEDORAS}

RESUMO - A colheita mecânica acarreta danificações nas sementes e pode comprometer sua qualidade. Neste contexto, objetivou-se neste trabalho, diagnosticar e avaliar o efeito de duas colhedoras: uma com sistema de trilha de fluxo axial e outra com sistema de trilha de fluxo tangencial, sob três regulagens de abertura do côncavo (1; 30 e $1 \mathrm{~mm}$, para colhedora de fluxo axial e 3,0; 15 e 3,0 mm, para colhedora de fluxo tangencial) e três rotações do cilindro $(1100 ; 450$ e 650 ou 930, dependendo do grau de umidade das sementes de $13,7 \%$ e $16,6 \%$, respectivamente, para colhedora de fluxo axial e 1000; 500 e 550 ou $800 \mathrm{rpm}$, dependente do grau de umidade de $13,7 \%$ e $16,6 \%$, respectivamente, para colhedora de fluxo tangencial) sobre a qualidade das sementes da cultivar de soja "ND 4910". Teores de água diferenciados foram obtidos em diferentes horários de colheita. A qualidade da semente foi avaliada pelos testes de germinação, índice de velocidade de germinação, velocidade de germinação, grau de umidade, porcentagem de pureza e vigor pelo teste de tetrazólio. Independente da colhedora, os resultados obtidos permitiram concluir que o dano mecânico foi o que mais reduziu a qualidade das sementes, com 16,6\% de grau de umidade, abertura de côncavo de 3 mm (axial) e $1 \mathrm{~mm}$ (tangencial) e rotação do cilindro de $1100 \mathrm{rpm}$ (axial) e 1000 (tangencial), ambas com as maiores rotações de cilindro utilizadas.

Palavras-chave: Glycine max. Regulagem de colhedoras. Rotação do cilindro.

\footnotetext{
*Corresponding Author

${ }^{1}$ Received for publication in 11/11/2014; accepted in 12/05/2015.

${ }^{2}$ Unioeste/Cascavel/CCET/PGEAGRI - 2069, University Street, - JD. University - Cascavel - PR - Zip code: 85819-110; fabiop.pacheco@gmail.com

${ }^{3}$ FAMV/UPF - Agronomy Course - Cumpus I - Neighborhood of São José. C.P. 611 Zip Code: 99001-970 Passo Fundo - RS, boller@upf.br.
} 


\section{INTRODUCTION}

The Brazilian agricultural production has increased in recent years, both in productivity and in cultivated area. These increases have come to demand higher quality and speed of harvest. When harvest is managed at inadequate stadium of seeds maturation, without observing the correct operating preparation, maintenance and adjustments of combines, there are some considerable losses on it, which decrease producers, productivity and profitability (FERREIRA, 2007).

According to Costa et al. (2002), mechanical harvesting, if it not performed with strict care, can provide significant losses in both quantity and quality of the harvested product. Carvalho Filho et al. (2005) also pointed out that crop losses are influenced both by factors that are inherent in the crop, mainly by factors related to the combine. Besides the direct injury to physiological quality, seeds with cracked tegument, cracks or light scarification are sources of infection and have their potential of storage affected by the attack of insects and microorganisms (MARCOS FILHO, 2005). Thus, not only large and visible injuries, but also small, micro or even invisible injuries by naked eye, depending on their place, can significantly reduce seed quality (LOPES et al., 1999).

The physiological quality, vigor and performance of soybean seeds may be influenced by factors such as the chosen cultivar (VASCONCELOS et al., 2009), tillage systems, crop sequence used (NAKAGAWA et al., 2003), sowing period (MOTTA et al., 2002), packaging during storage (GIURIZATTO et al., 2008), period of seed production (ALBRECHT et al., 2009), kind of combine used (MARCONDES et al., 2005; MARCONDES et al., 2010), moisture content at harvest (PESKE AND HAMER, 1997), among other factors.

According to Afonso Júnior and Corrêa (2000), the crush susceptibility of seeds is inversely related to a moisture content of the product at harvest. Carraro and Peske (2005) examined the use of soybean seeds in Paraná State and concluded that the mechanical injury and spoiling caused by moisture are the main causes of low quality in some seed batches. Costa et al. (2005) have studied the ecological zoning to crop soybeans and found out that the spoiling caused by moisture and mechanical injury are the main factors that contribute to reducing the quality of soybean seeds.

The speed, percentage and uniformity of germination on a seed batch are influenced by several internal conditions, by environmental factors and management practices during and after harvest (MARCOS FILHO, 2005).

A threshing mechanism decreases losses of seeds during the process, as well as reduces mechanical injuries transmitted to seeds and their correct separation. The combines with axial threshing sys- tem, in which the material takes the cylinder axis direction (known as rotor), present as possibility the decrease of mechanical injury rates, especially at seeds harvest in relation to the combines with tangential threshing system (CUNHA OLIVEIRA AND PIVA, 2009).

In this context, this study aimed at diagnosing and evaluating the effects of two combines: the first one with a threshing system of axial flow and the other with a threshing system of tangential flow, based on three adjustments of concave opening and three cylinder rotations at soybean harvest with two degrees of moisture content on seed quality.

\section{MATERIAL AND METHODS}

The crop was carried out under no-tillage system on a farm in Rio Bonito, Pontão city - RS, in 2008, latitude $-28^{\circ} 03^{\prime} 33^{\prime \prime}$ and longitude $52^{\circ} 40^{\prime} 38^{\prime \prime}$ with $683 \mathrm{~m}$ average altitude.

The soybean cultivar was 'ND 4910', with 377,000 plants per hectare and official recommended techniques were adopted for the crop. Seeds were harvested with combines Case ${ }^{\circledR}$ - Model 2388 Extreme and John Deere ${ }^{\circledR}$ - Model 8700. The first combine had a threshing system of axial flow, with a $280 \mathrm{hp}$ engine and rotor speed from 250 to 1150 rpm.

The rotor dimensions are $762 \mathrm{~mm}$ diameter and $2794 \mathrm{~mm}$ length, with transport wings, which allow increasing or decreasing as long as the material stays in a threshing system. The batter has a triangular section with three blades. The second combine uses the tangential flow (conventional), a threshing system with a $225 \mathrm{hp}$ engine, concave, and cylinder of bars, with a range of speeds from 380 to 1100 rpm. The cylinder diameter is $615.5 \mathrm{~mm}$ with 1.540 $\mathrm{mm}$ width and eight bars. The concave has a $104^{\circ}$ angle of involvement and 14 bars, while, the Thrasher has a square section with four blades.

The speed of both machines was stabilized at $5.0 \mathrm{~km} \mathrm{~h}^{-1}$, and the seed samples $(1.5 \mathrm{~kg})$ were collected at the exit of screws that supplied the bulk carrier of combines with four replications. Subsequently, the seeds were put in paper bags and just after the sampling collection, moisture content was determined using a particular 'Universal' model.

Seeds were harvested in mid-morning and had $16.6 \%$ moisture while those harvested in midafternoon showed $13.7 \%$ answer. Both combines were managed with three adjustments of threshing mechanisms for each moisture content (Table 1).

Four replications were collected for each treatment (combination of threshing mechanism, adjustment and moisture content). The manual harvest of four samples was considered as the control treatment.

Samples were packed and transported to the Laboratory of Seeds and Plants Analyzes from the 
Department of Exact and Technologic Sciences at the Western Paraná State University (UNIOESTE Campus of Cascavel). The percentage of germination, moisture content (BRAZIL, 2009), germination speed index (GSI) (MAGUIRE, 1962), germination rate (GR) were determined according to Edmond and Drapala (1958), as well as viability and vigor by tetrazolium test (FRANÇA NETO et al., 1999).

Table 1. Adjustments of threshing mechanisms of combines for soybean seeds with different moisture contents and adjustments.

\section{Combine}

\begin{tabular}{|c|c|c|c|c|c|c|}
\hline \multicolumn{7}{|c|}{ Combine } \\
\hline \multirow{2}{*}{ Adjustments } & \multicolumn{3}{|c|}{ Axial } & \multicolumn{3}{|c|}{ Tangential } \\
\hline & \multicolumn{2}{|c|}{ Cylinder rotation (rpm) } & $\begin{array}{c}\text { Concave } \\
\text { opening }(\mathrm{mm})\end{array}$ & \multicolumn{2}{|c|}{ Cylinder rotation (rpm) } & $\begin{array}{c}\text { Concave } \\
\text { opening }(\mathrm{mm})\end{array}$ \\
\hline HT & & 1100 & 10,0 & & 1000 & 3,0 \\
\hline LT & & 450 & 30,0 & & 500 & 15,0 \\
\hline \multirow{2}{*}{ IT } & $\begin{array}{lr}\text { Morning } & - \\
\text { moisture } & \text { content } \\
16.6 \% & \end{array}$ & 930 & 10,0 & $\begin{array}{l}\text { Moisture } \\
\text { content } \\
16.6 \%\end{array}$ & 800 & 3,0 \\
\hline & $\begin{array}{l}\text { Afternoon } \\
\text { moisture content } \\
13.7 \%\end{array}$ & 650 & 10,0 & $\begin{array}{l}\text { Moisture } \\
\text { content } \\
13.7 \%\end{array}$ & 550 & 3,0 \\
\hline
\end{tabular}

HT: Adjustment that provides the greater effect of threshing; LT: Adjustment that provides the lower effect of threshing; IT: Adjustment with threshing effect, considered ideal as it does not generate losses at the crop.

Each area sample (replication) was subdivided into two sub-samples, with a total of eight repetitions of each treatment and using the average of sub-samples for the analysis of variance. Thus, the experimental design was a $2 \times 2 \times 3$ factorial (combine $\mathrm{x}$ moisture content $\mathrm{x}$ adjustment), with four replications.

The data were submitted to ANOVA and averages were compared by Turkey test at $5 \%$ probability using SISVAR 5.0 software developed by Ferreira (2008). The data that were obtained on the percentage of germination and tetrazolium test were transformed into arc sen $\sqrt{(x+0,5) / 100}$ before their submission to the analysis of variance (BRASIL, 2009).

\section{RESULTS AND DISCUSSION}

The percentage of germination did not differ between both combines (Table 2). Similar results were obtained by Mesquita et al. (1999), who evaluated losses and physical quality of soybean seeds by mechanical harvesting from 95/96 and 97/98 crops in Brazil, and pointed out that the levels of mechanical injury did not dependent on age or brands from the studied combines.

In a study concerning mechanical injury and physiological quality of soybean seeds, harvested by conventional and axial threshing system, concluded that both combines, since they were conveniently used at harvest according to the specific adjustments, did not cause difference on physiological quality of soybean seeds (MARCONDES et al., 2005).

There were significant interactions between moisture content of seeds and the adjustments of combines. When moisture content was $16.6 \%$, the percentage of germination was influenced by the adjustments, but this did not happen to $13.7 \%$ moisture content. With the highest moisture content, the ideal threshing adjustments and the highest effect of threshing reduced the percentage of seed germination when compared with the lowest threshing adjustment.

According to this moisture content, the lowest threshing adjustment resulted in crop losses due to some threshing lack, so, its use is not indicated. Similar results were obtained by Costa et al. (2001), who reported slightly superiority in absolute values, with improvements on germination, vigor and viability from twelve soybean cultivars harvested in the States of Paraná, Santa Catarina and Mato Grosso, when the speed of threshing cylinder operated with rotation less than $500 \mathrm{rpm}$ for the tangential combine. On the other hand, when the seed moisture content was $13.7 \%$ at harvest, there was no effect of adjustments of combines on seeds germination. At 
this moisture content, the highest and the ideal threshing adjustments resulted in a superior germination than the one observed with $16.6 \%$ moisture content, which indicates the importance of respecting the ideal moisture content of seeds to minimize injury to the harvest.

Table 2. Averages of germination percentage (\%) of soybean seeds harvested with axial and tangential threshing mechanisms, adjusted according to threshing effect, with 16.6 and $13.7 \%$ moisture contents.

\begin{tabular}{|c|c|c|}
\hline Factor & \multicolumn{2}{|c|}{ Germination $(\%)$} \\
\hline Threshing mechanism & \\
\hline Axial & \multirow{2}{*}{\multicolumn{2}{|c|}{$\begin{array}{l}93 \mathrm{~A} \\
93 \mathrm{~A}\end{array}$}} \\
\hline 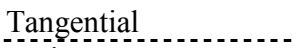 & & \\
\hline \multicolumn{3}{|l|}{ Moisture content } \\
\hline $16.6 \%$ & \multicolumn{2}{|c|}{$90 \mathrm{~B}$} \\
\hline $13.7 \%$ & \multicolumn{2}{|c|}{$97 \mathrm{~A}$} \\
\hline \multicolumn{3}{|l|}{ Adjustment } \\
\hline HT & \multicolumn{2}{|c|}{$89 \mathrm{~B}$} \\
\hline LT & \multicolumn{2}{|c|}{$98 \mathrm{~A}$} \\
\hline IT & \multicolumn{2}{|c|}{$93 \mathrm{~B}$} \\
\hline \multicolumn{3}{|c|}{ Interaction sliced between adjustments and moisture content of seeds } \\
\hline Adjustment & Moisture $1(16.6 \%)$ & Moisture $2(13.7 \%)$ \\
\hline HT & $82 \mathrm{Bb}$ & $96 \mathrm{Aa}$ \\
\hline LT & $98 \mathrm{Aa}$ & $98 \mathrm{Aa}$ \\
\hline IT & $89 \mathrm{Bb}$ & $96 \mathrm{Aa}$ \\
\hline
\end{tabular}

HT: The highest effect of threshing; LT: The lowest effect of threshing; IT: Ideal threshing

Averages followed by the same letter, uppercase in a column within each factor and lower-case letter in the row, do not differ among themselves by Tukey test at $5 \%$ probability. The presented data were obtained from the original observations followed by the letters obtained from the comparison of averages with the transformation in arcsine $\sqrt{ }(x+0.5) / 100$.

These observations can be justified by the reports of Carvalho and Nakagawa (1983), whereby moisture content of seeds, at the time of impact, is the only factor that plays the most important role among those that determine how much mechanically injured the seeds are. According to Table 3, it is observed that the germination rate (GR) showed no statistical difference for the analyzed parameters. The germination speed index (GSI) showed the highest average on $13.7 \%$ moisture content and the highest averages on adjustments with the lowest effect of threshing and ideal threshing, which had the lowest rotations of threshing mechanisms. Based on the analyzes of seeds moisture content, there is no difference among the combine and adjustment factors, whereas, for the moisture content factor, there was a difference among averages.

Seed batches with the highest germination rate, calculated by VG and GSI, are the most vigorous ones, so, there is a direct relation between the speed of germination and seeds vigor (KRZYZANOWSKI, VIEIRA AND FRANÇA NETO, 1999).

Table 3. Germination speed index ( GSI), germination rate (GR) and post-harvest moisture content determined in the laboratory, of soybean seeds for factors as combine, moisture content in the area and adjustment.

\begin{tabular}{|c|c|c|c|}
\hline Factor & GSI & GR & Post harvest moisture content (\%) \\
\hline \multicolumn{4}{|c|}{ Threshing mechanism } \\
\hline Axial & $29.9 \mathrm{~A}$ & $5.0 \mathrm{~A}$ & $9.7 \mathrm{~A}$ \\
\hline \multicolumn{4}{|c|}{$\begin{array}{l}\text { moisture content } \\
\text { moist }\end{array}$} \\
\hline $16,6 \%$ & $29.4 \mathrm{~B}$ & $5.0 \mathrm{~A}$ & $9.8 \mathrm{~A}$ \\
\hline $\begin{array}{l}13,7 \% \\
-\mathbf{A d j u s t m e n}\end{array}$ & $\begin{array}{l}30.6 \mathrm{~A} \\
-----\end{array}$ & $5.0 \mathrm{~A}$ & 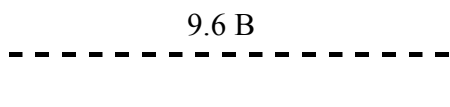 \\
\hline HT & $29.3 \mathrm{~B}$ & $5.0 \mathrm{~A}$ & $9.6 \mathrm{~A}$ \\
\hline $\mathrm{LT}$ & $30.7 \mathrm{~A}$ & $5.0 \mathrm{~A}$ & $9.7 \mathrm{~A}$ \\
\hline IT & $30.1 \mathrm{AB}$ & $5.0 \mathrm{~A}$ & $9.7 \mathrm{~A}$ \\
\hline
\end{tabular}

HT: The highest effect of threshing; LT: The lowest effect of threshing; IT: Ideal threshing

Averages followed by the same letter, uppercase in a column within each factor and lower-case letter in the row, do not differ among themselves by Tukey test at $5 \%$ probability. 
The purity of seeds on threshing mechanism factor presented difference among the averages, and the combine with a threshing system of tangential flow registered the highest percentage of pure seeds (Table 4). For moisture content, a significant difference was recorded, with the greatest physical purity at $13.7 \%$. On the adjustment factor, the values differed among themselves, with the greatest purity on the adjustment of the lowest effect of threshing, which averages that, on the adjustment with the lowest cylinder rotation, followed by adjustment of the ideal threshing and the greatest effect of threshing.

In the sliced interaction between adjustment and moisture content, they differed among themselves, although the highest adjustment was on the lowest effect of threshing. Among the adjustments, the highest values were for $16.6 \%$ moisture content on the adjustment of the highest effect of threshing and for $13.7 \%$ moisture content, on the adjustment of the lowest effect of threshing and ideal threshing.

When worked with beans crop and used an axial combine automotive, they could conclude that the purity percentage of grains was affected by the cultivar as well as by the combine speed $\left(3 \mathrm{~km} \mathrm{~h}^{-1}, 5\right.$ $\mathrm{km} \mathrm{h}^{-1}$ and $7 \mathrm{~km} \mathrm{~h}^{-1}$ ) and that the highest the speed of moving, the highest was the loss of grains, percentage of injured grains and cutting height, but the lowest was purity and germination at ten days after harvest (SILVA et al. (2009).

Table 4. Purity, the percentage of soybean seeds to factors as combine, moisture content seeds, adjustment and the sliced interaction between the adjustment $\mathrm{x}$ moisture content factors.

\begin{tabular}{|c|c|c|}
\hline \multirow{2}{*}{$\begin{array}{l}\text { Factors } \\
\text { Threshing mechanism }\end{array}$} & \multicolumn{2}{|c|}{ Purity $(\%)$} \\
\hline & \multirow{2}{*}{\multicolumn{2}{|c|}{$87.4 \mathrm{~B}^{(1)}$}} \\
\hline Axial & & \\
\hline Tangential & \multicolumn{2}{|c|}{$90.9 \mathrm{~A}$} \\
\hline \multicolumn{3}{|l|}{ Moisture content } \\
\hline $16.6 \%$ & \multicolumn{2}{|c|}{$88.5 \mathrm{~B}$} \\
\hline $13.7 \%$ & \multicolumn{2}{|c|}{$89.8 \mathrm{~A}$} \\
\hline \multicolumn{3}{|l|}{ Adjustment } \\
\hline HT & \multicolumn{2}{|c|}{$78.3 \mathrm{C}$} \\
\hline LT & \multicolumn{2}{|c|}{$96.6 \mathrm{~A}$} \\
\hline IT & \multicolumn{2}{|c|}{$92.5 \mathrm{~B}$} \\
\hline \multicolumn{3}{|c|}{ Interactions sliced between adjustment and moisture content of seeds } \\
\hline Adjustment & Moisture $1(16.6 \%)$ & Moisture $2(13.7 \%)$ \\
\hline HT & $79.6 \mathrm{Ca}^{(1)}$ & $77.1 \mathrm{Cb}$ \\
\hline LT & $96.0 \mathrm{Aa}$ & $97.2 \mathrm{Aa}$ \\
\hline IT & $90.0 \mathrm{Bb}$ & $95.0 \mathrm{Ba}$ \\
\hline
\end{tabular}

HT: The highest effect of threshing; LT: The lowest effect of threshing; IT: Ideal threshing

Averages followed by the same letter, uppercase in a column within each factor and lower-case letter in the row, do not differ among themselves by Turkey test at $5 \%$ probability. The presented data were obtained from the original observations followed by the letters obtained from the comparison of averages with the transformation in arcsine $\sqrt{ }(x+0.5) / 100$.

The percentage of broken seeds did not differ between the combines, however, they differed on moisture content and adjustments answers (Table 5). The highest percentage of broken seeds was observed at $13.7 \%$, on the adjustment of the highest effect of threshing from a combine of tangential flow and differed from other adjustments. In the sliced interaction of averages among the factors, both tested moisture contents had the highest percentage of broken seeds when harvested under the adjustment of the highest effect of threshing and so differing from the other treatments.

For the adjustment factor, the averages differed among themselves in the adjustment of the highest effect of threshing, with the highest percentage of broken seeds at $13.7 \%$ moisture content. Silva et al. (2009) observed that the speed of operation did not affect the percentage of broken beans grains during the harvest in the morning. However, in the afternoon, the lowest speed caused a higher percentage of broken grains than the other speeds. The authors defend that this happened because of a lower supply rate of the combine, associated with drier grain threshing.

When analyzed the effects of mechanical harvesting with a tangential combine concerning the qualitative losses of soybean seeds and observed that there was no influence from moisture content and concave opening on crushing seeds. However, the lowest percentage of broken seeds was observed in $500 \mathrm{rpm}$ rotation, which was the lowest rotation in this trial, but, there was an increase of such percentage by increasing the cylinder rotation (PINHEIRO NETO; GAMERO, 2000).

Threshing mechanism factor did not differ among the average percentages of crushed seeds (Table 6), which differed in moisture content factor, with the highest percentage at $16.6 \%$. The adjustment factor showed different answers among the observed averages, with the highest percentage of crushed seeds on the adjustment of the highest effect of threshing and this one differed from the adjustment of the lowest effect of threshing, which were similar to the ideal threshing adjustment. 
Table 5. Broken soybean seeds percentage for factors as a combine (axial and tangential), moisture content and adjustment and the sliced interaction between adjustment $\mathrm{x}$ moisture content factors.

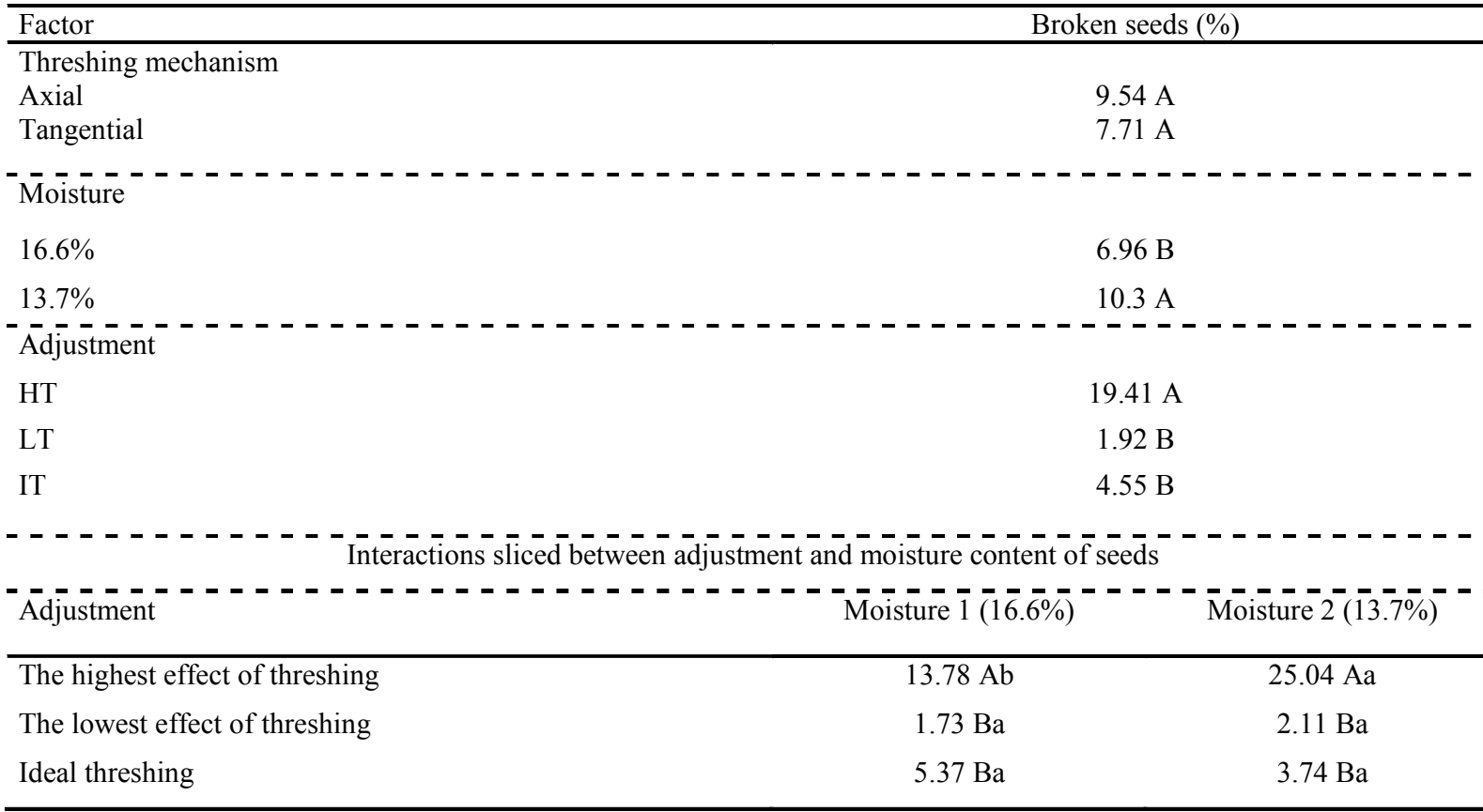

HT: The highest effect of threshing; LT: The lowest effect of threshing; IT: Ideal threshing

Averages followed by the same letter, uppercase in a column within each factor and lower-case letter in the row, do not differ among themselves by Tukey test at $5 \%$ probability. The presented data were obtained from the original observations followed by the letters obtained from the comparison of averages with the transformation in $\operatorname{arcsine} \sqrt{ }(x+0.5) / 100$.

Table 6. The crushed soybean seeds percentage for factors as a combine (axial and tangential), moisture content in the area, adjustment and the split between adjustment $\mathrm{x}$ moisture content factors.

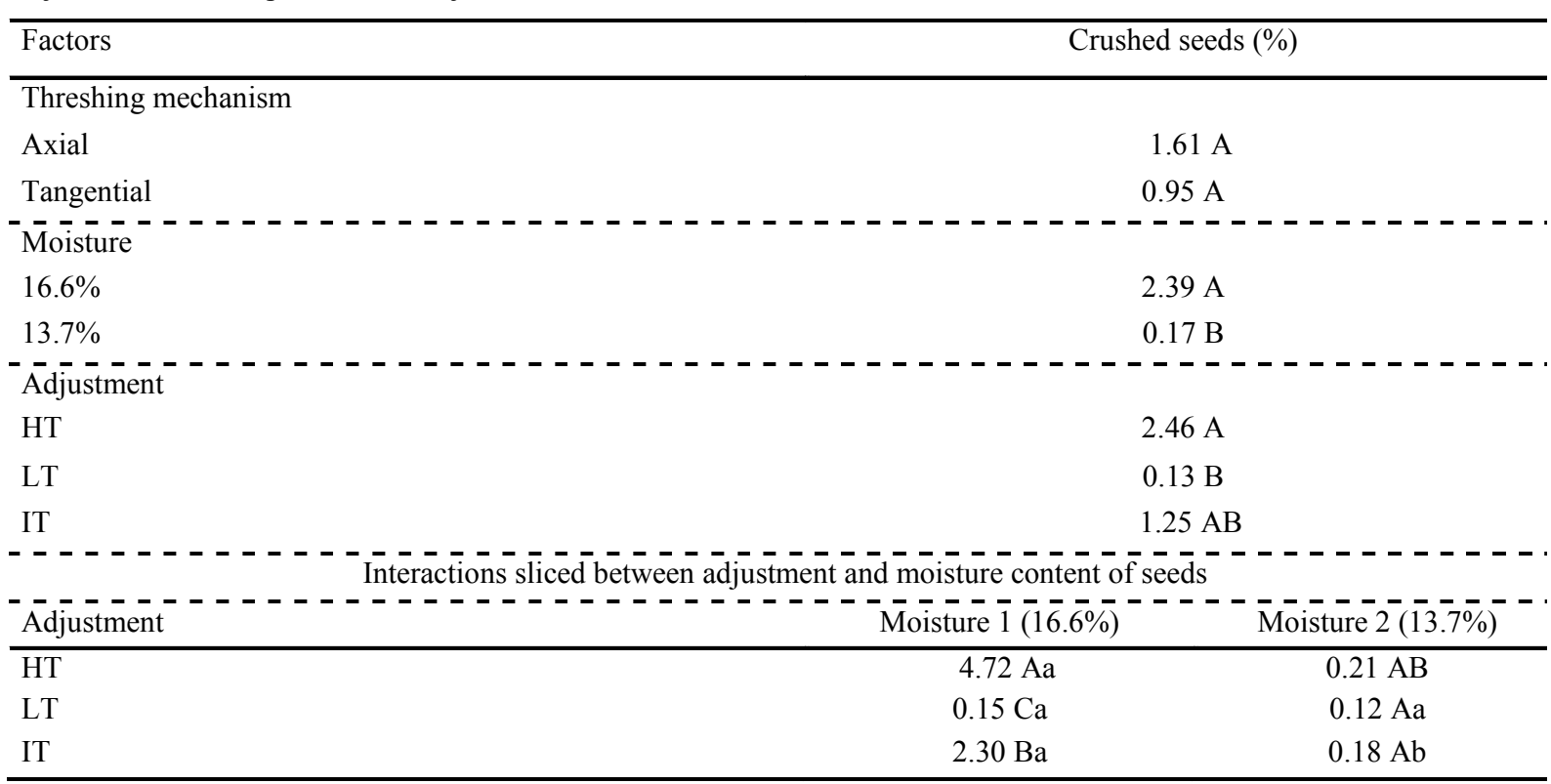

HT: The highest effect of threshing; LT: The lowest effect of threshing; IT: Ideal threshing

Averages followed by the same letter, uppercase in a column within each factor and lower-case letter in the row, do not differ among themselves by Tukey test at $5 \%$ probability. The presented data were obtained from the original observations followed by the letters obtained from the comparison of averages with the transformation in $\operatorname{arcsine} \sqrt{ }(\mathrm{x}+0.5) / 100$.

In the sliced interaction among factors, the averages for $16.6 \%$ moisture content differed among themselves, but the highest answer was observed in the adjustment of the highest effect of threshing. However, there was no difference at $13.7 \%$ moisture content. For the adjustments of the highest effect of threshing and the ideal one, the averages differed among themselves and the highest percentage of crushed seeds was at $16.6 \%$ moisture content.

The method of harvesting influences on the 
occurrence of mechanical injury in seeds, which can be caused by impacts, cuts, abrasions or pressure, whose result is the loss of quality (MARCOS FILHO, 2005). According to Carvalho and Nakagawa (2012), the mechanical injury by crushing increases from values of $16-18 \%$ moisture content.

At the time of impact, seed moisture content plays the most important role of the factors that determine the severity of the mechanical injury. When the moisture content is too high, the impact is distributed in a limited way, so almost all the impact force is concentrated in a relatively small region that is distributed around the point where it occurred. When the moisture content is at intermediate levels, the impact force is distributed evenly on the whole seed and in a soft way to cause little adverse effect. In practice, it can be stated that the mechanical injury by smashing increases as moisture content is reduced to values below 12-14\% (CARVALHO; NAKAGAWA, 2012).

Tables 5 and 6 were compared to observe that for $13.7 \%$ moisture content, there was the highest smashing and for $16.6 \%$ moisture content, there was the higher crushing of soybean seeds. These answers are in accordance with the authors already cited. However, the adjustments influenced on these factors, i.e., the adjustment with the lowest effect of threshing had the lowest percentage of crushing for both moisture contents, while the adjustment with the highest effect of threshing showed the highest percentage of crushed seeds in the same conditions of moisture content.

According to the analysis of averages of seeds viability (Table 07), it can be seen that the threshing mechanism factor did not affect the combines. However, moisture content and adjustment analyzes registered that there was a significant difference at $16.6 \%$ moisture content. The adjustment of the lowest effect of threshing showed the greatest viability, followed by the ideal threshing and the highest effect of threshing. Although, it was also observed that the greater the cylinder rotation, there was lower seed viability, when both moisture contents were compared.

The adjustments with the highest cylinder rotation, associated with the highest moisture content showed the lowest viability. According to the adjustment, it could be noted that, again, viability showed the lowest answer, as there was an increase in rotation. These results are similar to those found by Costa et al. (2002), in which the use of higher speeds of the cylinder, associated with other factors, caused a reduction in viability. Costa et al. (2001) reported in their trial that although, statistically, there was no significant difference, the seeds harvested at the lower rotational speed of cylinder showed a higher value of viability.

Table 7. Viability evaluated by tetrazolium test for factors as combine, moisture content in the area and adjustment and the sliced interaction among the regulating x moisture content factors.

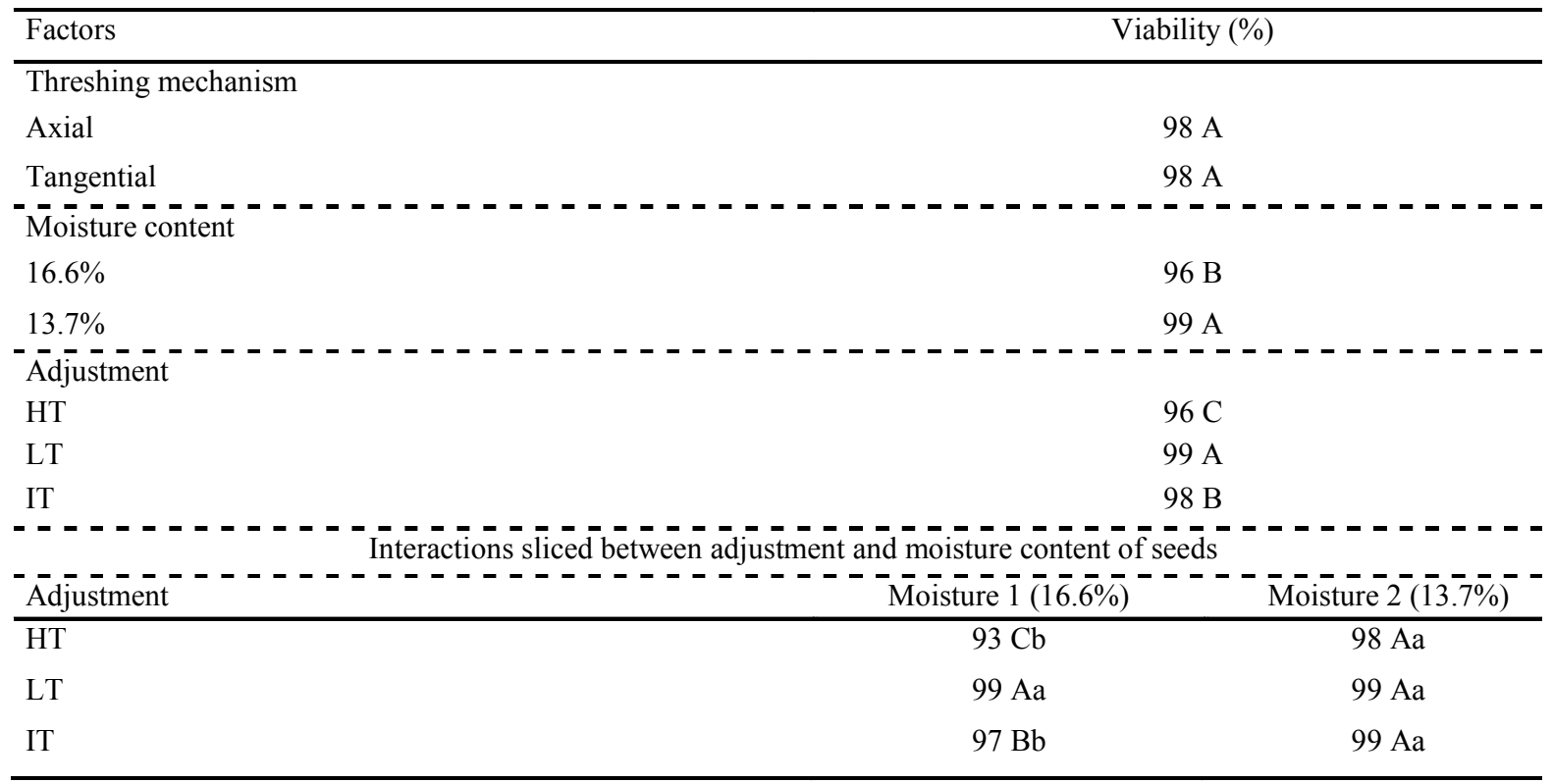

HT: The highest effect of threshing; LT: The lowest effect of threshing; IT: Ideal threshing

Averages followed by the same letter, uppercase in a column within each factor and lower-case letter in the row, do not differ among themselves by Tukey test at $5 \%$ probability. The presented data were obtained from the original observations followed by the letters obtained from the comparison of averages with the transformation in arcsine $\sqrt{ }(x+0.5) / 100$. 
It can be observed from Table 8 that the adjustment of the lowest effect of threshing showed the greatest vigor, followed by the adjustment of ideal threshing and the highest effect of threshing, respectively. Thus, it can be concluded that as there was an increase in cylinder rotation, the seeds showed lower vigor. Seed moisture content also caused some influence on vigor, so, it could be registered that for $13.7 \%$ moisture content, the adjustments of the lowest effect and ideal effect of threshing, associated with the lowest cylinder rotation, presented more vigor in relation to the adjustment of the highest effect of threshing.

On the other hand, for $16.6 \%$ moisture content, the influence occurred in the three adjustments, making clear that the greater cylinder rotation was, the smaller vigor percentage was. Similar results were obtained by Costa et al. (1996) and Pinheiro Neto and Gamero (2000), which demonstrated that the low rotation and lower moisture contents provide increased vigor of seed that are measured by tetrazolium test.

Table 8. The vigor of soybean seeds evaluated by tetrazolium test for the following factors: combine (axial and tangential), seed moisture content in the area and adjustment and the sliced interaction between adjustment $\mathrm{x}$ seed moisture content factors.

\begin{tabular}{|c|c|c|c|}
\hline Factors & \multicolumn{3}{|c|}{ Vigor (\%) } \\
\hline \multicolumn{4}{|c|}{ Threshing mechanism } \\
\hline Axial & \multicolumn{3}{|c|}{$91 \mathrm{~A}$} \\
\hline Tangential & \multicolumn{3}{|c|}{$91 \mathrm{~A}$} \\
\hline \multicolumn{4}{|c|}{ Möisture content } \\
\hline $16.6 \%$ & \multicolumn{3}{|c|}{$89 \mathrm{~B}$} \\
\hline $13.7 \%$ & \multicolumn{3}{|c|}{$93 \mathrm{~A}$} \\
\hline \multicolumn{4}{|c|}{ 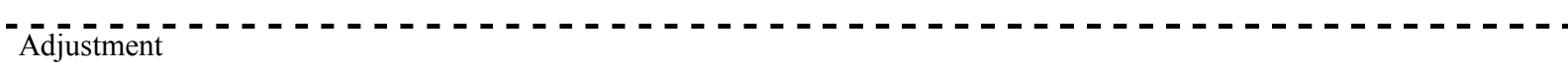 } \\
\hline HT & \multicolumn{3}{|c|}{$86 \mathrm{C}$} \\
\hline $\mathrm{LT}$ & \multicolumn{3}{|c|}{$94 \mathrm{~A}$} \\
\hline IT & \multicolumn{3}{|c|}{$92 \mathrm{~B}$} \\
\hline \multirow{2}{*}{\multicolumn{4}{|c|}{$\begin{array}{l}\text { Interactions sliced between adjustment and moisture content of seeds } \\
\text { Ädjustment }\end{array}$}} \\
\hline & & & \\
\hline HT & $82 \mathrm{Cb}$ & & $91 \mathrm{Ba}$ \\
\hline LT & $95 \mathrm{Aa}$ & & $94 \mathrm{Aa}$ \\
\hline IT & $91 \mathrm{Bb}$ & & 94 Aba \\
\hline
\end{tabular}

HT: The highest effect of threshing; LT: The lowest effect of threshing; IT: Ideal threshing

Averages followed by the same letter, uppercase in a column within each factor and lower-case letter in the row, do not differ among themselves by Tukey test at $5 \%$ probability. The presented data were obtained from the original observations followed by the letters obtained from the comparison of averages with the transformation in arcsine $\sqrt{ }(x+0.5) / 100$

On Table 9, it can be observed that averages of deterioration caused by moisture, for threshing mechanism factor, showed the greatest answers in the axial mechanism. Thus, for moisture content factor, the highest average was for seeds harvested at $13.7 \%$ moisture content. For the adjustment, the highest averages were in the adjustment of the lowest effect of threshing and ideal one, differing from the adjustment of the highest effect of threshing.

On the sliced interaction of factors as adjustment and threshing mechanism, there is a difference between averages of combine that have only threshing system and axial flow, with further deterioration by moisture in seeds harvested under the adjustment of the lowest effect of threshing and ideal threshing, which differ from the adjustment of the highest effect of threshing, so, the adjustment with less cylinder rotation showed the lowest average of deterioration caused by moisture.

Among the adjustment averages, the values were different only for the adjustment of ideal threshing between combines and the axial showed the highest average. This problem can be minimized, according to Mesquita et al. (1999) and Costa et al. (1996), with accurate adjustments of the threshing system of machines as well as monitoring daily seed moisture content, harvesting at mild temperature.

There is no difference in the percentages of mechanical injury between threshing mechanisms (Table 10). At $16.6 \%$ moisture content, it was obtained the highest percentage of mechanical injury on the adjustment of ideal threshing. For combine adjustment, the injuries increased as cylinder rotation increased, according to the sequence of the lowest effect of threshing, ideal threshing and the highest effect of threshing. 
Table 9. Percentages of deterioration by the moisture of soybean seeds evaluated by tetrazolium test for factors as a threshing mechanism, seed moisture content in the area and adjustment and the sliced interaction between the adjustment $\mathrm{x}$ moisture content factors.

\begin{tabular}{|c|c|c|}
\hline Factors & \multicolumn{2}{|c|}{ Deterioration by moisture (\%) } \\
\hline \multicolumn{3}{|c|}{ Threshing mechanism } \\
\hline Axial & \multicolumn{2}{|c|}{$5.75 \mathrm{~A}$} \\
\hline \multicolumn{3}{|c|}{ 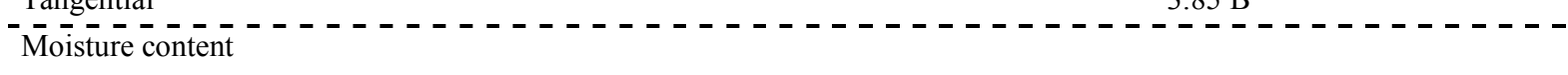 } \\
\hline $16.6 \%$ & \multicolumn{2}{|c|}{$3.62 \mathrm{~B}$} \\
\hline \multicolumn{3}{|c|}{ 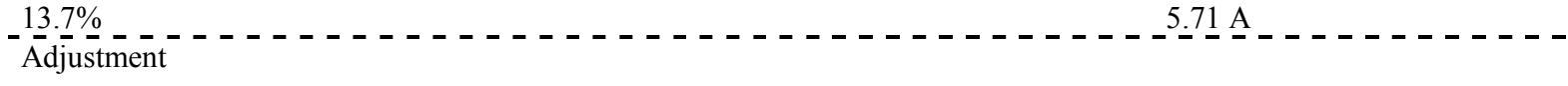 } \\
\hline HT & \multicolumn{2}{|c|}{$3.50 \mathrm{~B}$} \\
\hline $\mathrm{LT}$ & \multicolumn{2}{|c|}{$4.75 \mathrm{~A}$} \\
\hline \multicolumn{3}{|c|}{ 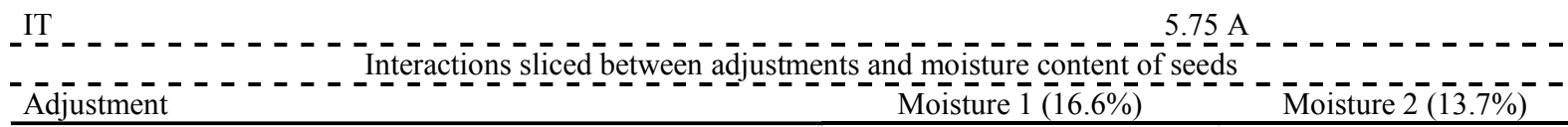 } \\
\hline HT & $2.87 \mathrm{Ba}$ & $4.12 \mathrm{Aa}$ \\
\hline LT & $6.00 \mathrm{Aa}$ & $3.50 \mathrm{Aa}$ \\
\hline IT & $8.37 \mathrm{Aa}$ & $3.12 \mathrm{Ab}$ \\
\hline
\end{tabular}

HT: The highest effect of threshing; LT: The lowest effect of threshing; IT: Ideal threshing.

Averages followed by the same letter, uppercase in a column within each factor and lower-case letter in the row, do not differ among themselves by Tukey test at $5 \%$ probability. The presented data were obtained from the original observations followed by the letters obtained from the comparison of averages with the transformation in $\operatorname{arcsine} \sqrt{ }(\mathrm{x}+0.5) / 100$.

Table 10. Mechanical injury of soybean seeds evaluated by tetrazolium test for factors as combine, moisture content and adjustment and the sliced interaction between the adjustment $\mathrm{x}$ seed moisture content factors.

\begin{tabular}{|c|c|c|}
\hline Factors & \multicolumn{2}{|c|}{ Mechanical injury (\%) } \\
\hline \multicolumn{3}{|c|}{ Threshing mechanism } \\
\hline Axial & \multicolumn{2}{|c|}{$23.58 \mathrm{~A}$} \\
\hline \multirow{2}{*}{\multicolumn{3}{|c|}{$\begin{array}{l}\text { Tangential } \\
- \text { Moisture content }\end{array}$}} \\
\hline & & \\
\hline $16.6 \%$ & \multicolumn{2}{|c|}{$22.79 \mathrm{~A}$} \\
\hline \multicolumn{3}{|c|}{ 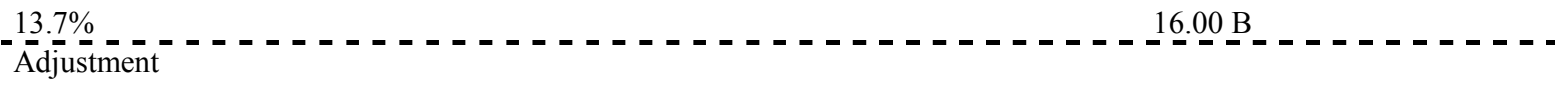 } \\
\hline HT & \multicolumn{2}{|c|}{$30.75 \mathrm{~A}$} \\
\hline LT & \multicolumn{2}{|c|}{$8.81 \mathrm{C}$} \\
\hline IT & \multicolumn{2}{|c|}{$18.62 \mathrm{~B}$} \\
\hline \multirow{2}{*}{\multicolumn{3}{|c|}{ 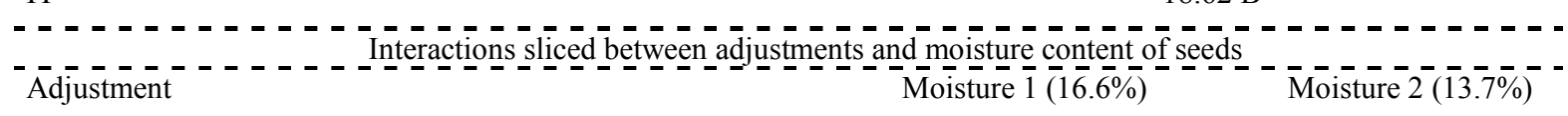 }} \\
\hline & & \\
\hline HT & $34.25 \mathrm{Aa}$ & $27.25 \mathrm{Ab}$ \\
\hline LT & $9.87 \mathrm{Ca}$ & $7.75 \mathrm{Ca}$ \\
\hline IT & $24.25 \mathrm{Ba}$ & $13.00 \mathrm{Bb}$ \\
\hline
\end{tabular}

HT: The highest effect of threshing; LT: The lowest effect of threshing; IT: Ideal threshing

Averages followed by the same letter, uppercase in a column within each factor and lower-case letter in the row, do not differ among themselves by Tukey test at $5 \%$ probability. The presented data were obtained from the original observations followed by the letters obtained from the comparison of averages with the transformation in arcsine $\sqrt{ }(x+0.5) / 100$. 
In the sliced interaction among the averages, there is a difference between moisture contents, with the highest mechanical injury in the adjustment of the highest effect of threshing. Among the adjustments of the highest effect of threshing and the ideal one, the values differ among themselves, with a greater mechanical injury to seeds at $16.6 \%$ moisture content.

There was not recorded significant difference among the percentages of mechanical injury of seeds harvested with a conventional and axial combine, harvested below $12 \%$ moisture content (MARCONDES et al., 2005). Yet, when the threshing mechanism factor was evaluated, it is observed that Mesquita et al. (1999) obtained similar results to this trial, since they did not find any statistical differences of mechanical injury in four combines. So, it can be assumed that, if combines are well adjusted, they have no influence on the mechanical injury in soybean seeds.

A high cylinder rotation associated with a small concave opening, at harvest, increased mechanical injury, especially when seeds were harvested below $12.5 \%$ moisture content (PINHEIRO NETO; GAMERO, 2000). While in this study, the association of higher seed moisture content, which, in this case, is $16.6 \%$, to the adjustment of the higher speed of cylinder rotation, caused a higher percentage of mechanical injury. Silva et al. (2009) analyzed the direct harvest (when there is no pile production or use of batter) of beans with an automotive axial combine and concluded that for the same mechanisms threshing of the machine, the injury to grains was influenced by the speed of combine operation in the area as well as by the seed moisture content.

When used an axial combine, at $13 \%$ seed moisture content and presented results of $76 \%$ vigor, $94 \%$ viability and $28.15 \%$ of mechanical injury in soybean seeds, similar to the adjustment of the highest effect of threshing with $82 \%$ vigor, 93\% viability and $34.25 \%$ of mechanical injury (LOPES et al., 2011). When the adjustment of the lowest effect of threshing was used with $13.7 \%$ seed moisture content, there was a reduction of $71.6 \%$. Therefore, at $16.6 \%$ moisture content, such reduction was $77.4 \%$ of mechanical injury when compared with the adjustment of the highest effect of threshing.

In general, it can be stated that the used models of combines did not affect germination, broken seeds percentage, viability or mechanical injury percentage of soybean seeds. The highest purity was observed in seeds harvested by tangential flow combine. On the other hand, the greatest injury caused by moisture was observed in seeds harvested by a tangential flow combine.

The seeds harvested with $13.7 \%$ moisture content at harvest showed the highest germination, germination speed index, purity, vigor, broken seeds percentage and the least mechanical injury, crushed seeds percentage and seed viability.

The adjustment with the lowest cylinder rotation $(450 \mathrm{rpm}$ for axial and $500 \mathrm{rpm}$ for tangential) showed the highest percentage of germination, vigor, purity, germination speed index, viability, the least mechanical injury and the least broken and crushed seeds percentages.

When the seed moisture content at harvest is around $13.7 \%$, there is the highest percentage of broken seeds, while at $16.6 \%$ seed moisture content, there is greater crushing of soybeans, regardless of combine adjustment.

\section{CONCLUSIONS}

Under the conditions that this trial was carried out, it can be concluded that for the highest degree of soybean seeds purity, it is recommended to use a tangential flow combine.

At harvest, the lowest moisture content $(13.7 \%)$ provides a better quality of seeds, and this was obtained at harvest in the afternoon. On-combine adjustment, regardless of the model, it is recommended to use low speeds of the cylinder (450 to $500 \mathrm{rpm}$ ) when the moisture content is close to $13.7 \%$, to reduce seeds injuries. At higher moisture contents $(16.6 \%)$, the highest cylinder rotations can provide a reduction on seeds breaking. It is also recommended, according to the possibilities, that the adjustment of cylinder rotation should be based on seed moisture content at harvest, since their injuries can be reduced when keeping better quality than no adjustment.

\section{REFERENCES}

ALBRECHT, L. P. et al. E Sementes de soja produzidas em épocas de safrinha na região oeste do Estado do Paraná. Acta Scientiarum Agronomy, Maringá, v. 31, n. 1, p. 121-127, 2009.

AFONSO JÚNIOR, P. C.; CORRÊA, P. C. Efeitos imediato e latente da secagem de sementes de feijão colhidas com diferentes níveis de umidade. Ciência e Agrotecnologia, Lavras, v. 24, ed. especial, p. 3340, 2000.

BRASIL. Congresso Nacional. Lei $\mathrm{n}^{\mathbf{0}}$ 10.711, de 05 de agosto de 2003. Dispõe sobre o sistema nacional de sementes e mudas e dá outras providências. Brasília, 2003.

BRASIL. Ministério da Agricultura, Pecuária e Abastecimento. Regras para análise de sementes. Ministério da Agricultura, Pecuária e Abastecimento. Secretaria de Defesa Agropecuária. Brasília: Mapa/ ACS, 2009. 399 p. 
CARRARO, I. M.; PESKE, S. T. Uso de semente de soja no estado do Paraná. Revista Brasileira de Sementes, Brasília, v. 27, n. 2, p. 75-80, 2005.

CARVALHO FILHO, A. et al. Perdas na colheita mecanizada de soja no triângulo mineiro. Revista Nucleus, Ituverava, v. 3, n. 1, p. 57-60, 2005.

CARVALHO, N. M.; NAKAGAWA, J. Sementes: ciência, tecnologia e produção. 5. ed. Jaboticabal, SP: FUNEP, 2012. 590 p.

COSTA, N. P et al. Efeito da colheita mecânica sobre a qualidade de sementes de soja. Revista Brasileira de Sementes, Brasília, v. 18, n. 2, p. 102107, 2001.

COSTA, N. P et al. Avaliação da qualidade de sementes e grãos de soja provenientes da colheita mecanizada, em diferentes regiões do Brasil. Engenharia Agrícola, Jaboticabal, v. 22, n.2, p. 211 $-219,2002$.

COSTA, N. P. Validação do zoneamento ecológico do estado do Paraná para produção de sementes de soja. Revista Brasileira de Sementes, Brasília, v. 27, n. 1, p. 37-44, 2005.

CUNHA, J. P. R. da; PIVA, G.; OLIVEIRA, C. de. Efeito do sistema de trilha e da velocidade das colhedoras na qualidade de sementes de soja. Bioscience Journal, Uberlândia, v. 25, n. 4, p. $37-42,2009$

DELOUCHE, J. C. Deterioração de sementes. Seed News, Pelotas, v. 6, n. 6, p. 24-31, 2002.

EDMOND, J. B.; DRAPALA, W. J. The effects of temperature, sand and soil, and acetone on germination of okra seed. Proceedings of the American Society for Horticutural Science, Ithaca, v. 1, n. 71, p. 428-434, 1958.

FERREIRA, I. C. Perdas quantitativas na colheita de soja em função da velocidade de deslocamento e regulagens no sistema de trilha. Engenharia na Agricultura, Viçosa, v. 15, n. 2, p. 141-150, 2007.

FERREIRA, D.F. SISVAR: um programa para análises e ensino de estatística. Revista Científica Symposium, Lavras, v. 6, n. 2, p. 36-41, 2008.

FRANÇA NETO, J. B.; KRZYZANOWSKI, F. C.; COSTA, N. P. Metodologia do teste de tetrazólio em sementes de soja. In: KRZYANOWSKI, F. C.; VIEIRA, R. D.; FRANÇA NETO, J. B. (Ed.). Vigor de sementes: conceitos e testes. Londrina, PR: ABRATES, 1999. v.1, cap. 8, p. 1-26.
GIURIZATTO, M. I. K. et al. Qualidade fisiológica de sementes de soja submetidas ao hidrocondicionamento. Acta Scientiarum Agronomy, Maringá, v. 30, supl., p. 711-717, 2008.

KRZYZANOWSKI， R. C.; VIEIRA， R. D.; FRANÇA NETO, J. B. Vigor de sementes: conceitos e testes. 1. ed. Londrina, PR: ABRATES, 1999. $218 \mathrm{p}$

LOPES, R. A. P.; NÓBREGA, L. H. P.; PEREIRA, J. O. Qualidade física e fisiológica e perdas de sementes de milho colhidas em espigas por uma colhedora adaptada. Engenharia Agrícola, Jaboticabal, v. 19, n. 1, p.187-198, 1999.

MAGUIRE, J. D. Seeds of germination-aid selection and evaluation for seedling emergence and vigor. Crop Science, Madison, v. 2, n. 1, p. 176-177, 1962.

MARCONDES, M. C.; MIGLIORANZA, E.; FONSECA, I. C. B. de. Danos mecânicos e qualidade fisiológica de semente de soja colhida pelo sistema convencional e axial. Revista Brasileira de Sementes, Brasília, v. 27, n. 2, p. 125-129, 2005.

MARCONDES, M. C.; MIGLIORANZA, E.; FONSECA, I. C. de B. Qualidade de sementes de soja em função do horário de colheita e do sistema de trilha de fluxo radial e axial. Engenharia Agrícola, Jaboticabal, v. 30, n. 2, p. 315-321, 2010.

MARCOS FILHO, J. Fisiologia de sementes de plantas cultivadas. 1 . ed. Piracicaba, SP: FEALQ, 2005. $495 \mathrm{p}$

LOPES, M. M. et al. Efeitos dos danos mecânicos e fisiológicos na colheita e beneficiamento de sementes de soja. Bioscience Journal, Uberlândia, v. 27 , n. 2 , p. $230-238,2011$.

MESQUITA, C. M. et al. Colheita mecânica da soja: avaliação das perdas e da qualidade física do grão. Engenharia Agrícola, Jaboticabal, v. 18, n. 3, p. 44$53,1999$.

MESQUITA, C. M.; et al. Perfil da colheita mecânica da soja no Brasil: safra 1998/1999. Engenharia Agrícola, Jaboticabal, v. 22, n. 2, p. 398 $-406,2002$.

MOTTA, I. DE S. et al. Época de semeadura em cinco cultivares de soja. I. Efeito nas características agronômicas. Acta Scientiarum Agronomy, Maringá, v. 24, n. 5, p. 1275-1280, 2002.

NAKAGAWA, J. Testes de vigor baseados no desempenho das plântulas. In: KRZYZANOSKI, F.C.; VIEIRA, R.D.; FRANÇA NETO, J.B. (Ed.). Vigor de sementes: conceitos e testes. Londrina, 
PR: ABRATES, 1999. v. 1. cap. 2. p. 1-24.

NAKAGAWA, J.; et al. Qualidade de sementes de trigo e de soja em função de sistemas de preparo de solo e da sucessão de culturas. Acta Scientiarum: Agronomy, Maringá, v. 25, n. 1, p. 73-80, 2003.

PESKE, S. T.; HAMER, E. Colheita de sementes de soja com alto grau de umidade. II - Qualidade fisiológica. Revista Brasileira de Sementes, Brasília, v. 19, n. 1, p. 66-70-1997.

PINHEIRO NETO, R.; GAMERO, C. A. Efeito da colheita mecanizada nas perdas qualitativas de sementes de soja (Glycine max (L.) Merrill). Engenharia Agrícola. Jaboticabal, v. 20, n. 3, p. 250 $-257,2000$.

SILVA, J. G.; AIDAR, H.; KLUTHCOUSKI, J. Colheita direta de feijão com colhedora automotriz axial. Pesquisa Agropecuária Tropical; Goiânia, v. 39, n. 4 , p. 371-379, 2009.

VASCONCELOS, E. S. de et al. Qualidade fisiológica de sementes de cultivares e linhagens de soja no Estado de Minas Gerais. Acta Scientiarum: Agronomy, Maringá, v. 31, n. 2, p. 307-312, 2009. 